\title{
Evaluation of Enzyme Cellulase Production and it's Activity, Isolated from Local Fungi
}

\author{
*Mohammed H. Mushrif ${ }^{1}$, Luai F. Zghair ${ }^{2}$, Muzahim Alkabban ${ }^{3}$ \\ Faculty of Medicine; Al-Iraqia University; Baghdad; Iraq
}

\begin{abstract}
Eight Fungal species were isolated from the rhizosphere of wheat Triticum aestivum ( Trichoderma harzianum, T.viride, T.longibrachiatum, Alternaria alternate, Fusarium solan, Aspergillus niger, Rhizoctonia solani and Fusarium oxysporum). All the isolated fungi had the capacity to cellulase enzyme production in solid media (CMC-Agar), moreover, T.viride gave the highest capability for the production of the enzyme (6.14). Rhizoctonia solani gave less productive ratio (3.0). Quantitative test using Mandel liquid media showed that the fungus T.viride had the highest activity of cellulase enzyme (4.39 U/ml), however this fungus had the greatest biomass $(8.96 \mathrm{~g} / \mathrm{L})$. The fungus Rhizoctonia solani gave lower enzyme activity $(2.04 \mathrm{U} / \mathrm{ml})$ and its biomass reached to $(4.65 \mathrm{~g} / \mathrm{L})$. Studying of different carbon sources for the fungus $T$. viride showed that sucrose was the best carbon source used with the liquid media for cellulase activity $(3.87 \mathrm{U} / \mathrm{ml})$, and the biomass $(2.83 \mathrm{~g} / \mathrm{L})$. From these findings, such fungi able to produce enzymes when activated depending on the substrate and cultured media.
\end{abstract}

Keywords: Fungi, cellulace enzyme activity.

\section{Introduction}

Cellulose is composed of glucose molecules joined by $\beta$ (1 4) glucosidic bonds, which makes it relatively resistant to hydrolysis and organic stores. This will make difficulty in the obtaining of glucose from cellulose according to the enzyme cellulase activity ${ }^{[1,2]}$.

Human and most Mammals cannot digest cellulose due to the absence of this enzyme capable of breaking the bonds between glucose units, however ruminants can do. Cellulose is one of the most abundant carbohydrate in the nature, it makes about $(15-60 \%)$ of the wall components of the plants ${ }^{[3]}$.

The important microorganisms ( bacteria and fungi ) studied by others ${ }^{[4]}$, make solution to disassemble cellulose into simple sugar that are easily used in many industrial fields to produce valuable materials ${ }^{[5]}$.

The ability of microorganisms to analyze cellulose is due to their production of cellulase which breaks the glycosidic bonds between the glucose molecules, as important energy sources of the cells and an essential sources for oxidation. This is occur by various microorganisms used in the industry, medical and food products such as alcohol production, organic acids, antibiotics and animal food production ${ }^{[6]}$. This enzyme is added to the animal feed as an adjuvant for digestion and used in the textile and in the paper industries and genetic engineering ${ }^{[2]}$.

Cellulase is an integrated enzyme complex, composed of three iso-enzymes that contribute together to the cellulose $\beta(1-4)$ linkage and are fully melted by breaking glycoside bonds $^{[7]}$ :

1. Endo- 1,4- $\beta$-D- glucanase (Mcase, EC.3.2.1.4).

2. Exo - 1,4- $\beta$-D glucanase (Cellobiohydrolase, EC.3.2.1.91).

3. $\beta$-Glcosidase ( Cellobiase, EC.3.2.1.21).

Growth of fungus and bacteria due to the activity of cellulase enzyme in the industrial and agricultural wastes then conversion of cellulose to a vital materials benefit, is one of the most important solutions for cellulose elimination as an environmental pollution ${ }^{[4]}$. Moreover, the conversion of cellulose to simple sugar in an enzymatic hallucinogenic manner using cellulase enzymes produced from microbiological proposals the task of producing alternative fuels (ethanol) ${ }^{[8]}$.

The economic importance of the cellulase enzyme produced by microorganisms such as Trichoderma ,Aspergillus , Cladosporium, brought attention for development and designing of different types of researches ${ }^{[4,9]}$.

The importance of this work comes from the fact that it highlights the role of some fungi in the production of cellulase enzyme obtained from local isolate of fungus that have high ability for enzyme production, as well as some effect of carbon sources in the production of the enzyme by T.Viride fungus.

\section{Materials and Methods}

\section{1) Fungal Isolates}

Eight different isolates were used in this work ( Trichoderma harzianum, T.viride, T.longibrachiatum, Alternaria alternate, Fusarium solan, Aspergillus niger, Rhizoctonia solani and Fusarium oxysporum).

All samples were isolated from the around root of the wheat plant Triticum aestivum at a depth $(5-10 \mathrm{~cm})$, using the culture media (PDA Potato-Dextrose Agar). Five grams of soil sample was taken, dried, grinded and then spread over a petridish containing the culture media (PDA). Penicillin was added to avoid bacterial growth.

Dishes were incubated at $\left(25 \pm 2^{\circ} \mathrm{C}\right)$ For a week with a daily examination starting from the third day. Species were identified by examining the development of colonies by the light microscope. Depending on the shape and color of the colonies in addition to the microscopic examination of the branches of mycelium and spores formed for identification of fungi ${ }^{[9,10]}$.

\section{Volume 6 Issue 7, July 2017 www.ijsr.net}




\section{International Journal of Science and Research (IJSR) \\ ISSN (Online): 2319-7064}

Index Copernicus Value (2015): 78.96 | Impact Factor (2015): 6.391

A pure sample of the studied species was kept a slope in the test tubes in the fridge at $4^{\circ} \mathrm{C}$, the samples were renewed every two weeks to maintain the vitality and effectiveness of the fungal growth.

\section{Cultivation media}

\section{Solid media:}

A qualitative test was performed using the solid media for detecting the permeability of the fungal growth obtained for production of cellulase enzyme using Carboxymethyl Cellulose Agar(CMC) Which consists of the following as $\mathrm{g} /$ L ( 10.0 CMC - Na Salt, 20.0 Agar, 2.0 $\mathrm{NaNO}_{3}, 0.5 \mathrm{MgSO}_{4}$ $.7 \mathrm{H}_{2} \mathrm{O}, 1.0 \mathrm{~K}_{2} \mathrm{HPO}_{4}, 0.01 \mathrm{FeSO}_{4}$ and $0.5 \mathrm{KCl}$ ).

The media is prepared by dissolving the above materials in distilled water ,except for CMC-Na salt is gradually added using a magnetic stirrer with heating till media homogenized. The $\mathrm{pH}$ was adjusted to 6.0 using $\mathrm{HCl}$ acid and sodium water, for sterilizing autoclave at $121^{\circ} \mathrm{C}$ for 15 minutes was used.

Media was distributed in sterile petridishes, then after solidification of media a disc of fungal colony was added to each petridish of a diameter $5 \mathrm{~mm}$, left for a week after inoculation at $\left(28 \pm 2^{\circ} \mathrm{C}\right)$ and checked daily till five days ${ }^{[5,11]}$.

Production of enzyme was observed by the appearance of a pale zone in the media around the fungal colony (figure 1).

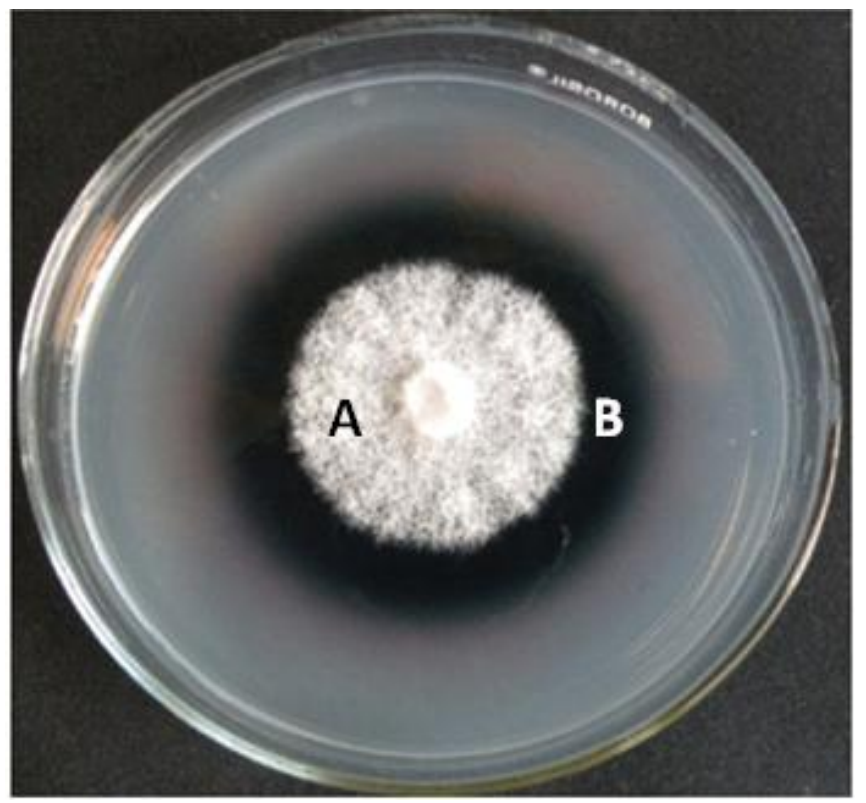

Figure 1: Detection of cellulase enzyme production by fungal isolate in the solid media. (A) - Fungal colony diameter. (B) - Decomposition diameter.

Appearance of the pale zone indicates decomposition of CMC media by distinctive cellulase enzyme in the solid medium. The dishes were removed from incubator after five days and the developing of fungal colony was measured and the diameter of the pale zone for each fungal isolates were estimated as production of cellulase enzyme using the following equation (Fungal of the production of cellulase enzyme $=$ the diameter of the decomposition / diameter of the fungal colony) $)^{[11]}$.

\section{Liquid media:}

Using Mendel's media which consists of the following materials prepared as $\mathrm{g} / \mathrm{l}$ of $(0.3 \mathrm{MgSO} 4.7 \mathrm{H} 2 \mathrm{O}, 10.0$ Cellulose, 2.0 KH2PO4, 0.005 FeSO4 .7 H2O, 1.0 peptone, $0.002 \mathrm{CoCl} 2,0.0014 \mathrm{ZnSO} 4$. H2O, 1.4 (NH4)2 SO4, 0.3 $\mathrm{CaCl} 2,0.3$ Urea).

All the above components of the media were dissolved in distilled water except, urea. The prepared media was adjusted to a pH 6.0 and distributed as $(50 \mathrm{ml})$ in each conical flasks size $(250 \mathrm{ml})$, closed tightly with cotton, wrapped with aluminum foil and sterilized under the same above condition ${ }^{[12]}$

Urea was added under sterilized conditions, and flasks were inoculated with a disk of the fungal colony of a diameter (5 $\mathrm{mm}$ ) for a week ${ }^{[13]}$. Flasks were incubated in the shaking incubator at $\left(28 \pm 2^{\circ} \mathrm{C}\right)$ and a 150 cycles per minute. Flasks were then withdrawn from the incubator after 7 days of incubation and the final $\mathrm{pH}$ was measured of each flask. The filtration process was then carried out for the counting of each flask from the cultured media using filtration papers (Whatman No.1).

Filter sheets of the biomass were dried in the oven at $70^{\circ} \mathrm{C}$ for 24 hours, and the biomass weight was then measured and the differences of the weights using a sensitive balance were calculate.

The supernatant was used for measuring the enzymatic efficacy of the fungus. Sodium benzoate was add as $1 \mathrm{~g} / 1$ to stop the growth of fungi, then kept in the refrigerator at $4{ }^{\circ} \mathrm{C}$ until use ${ }^{[9]}$

Enzyme cellulase activity was measured by estimation of free D - glucose by Filter Paper assay method ${ }^{[7]}$.

Taking $0.5 \mathrm{ml}$ from suspension in a test tube of $18 \mathrm{ml}$ then 1 $\mathrm{ml}$ of the solution $\mathrm{Na}$ - citrate buffer was added of a $\mathrm{pH} 4.8$, then immerse the filter paper strips(whatman No.1, size $1 \times 6$ $\mathrm{cm}$ and $50 \mathrm{mg}$ in weight) in the mixture.

The contained tube is incubated for 1 hour at $50^{\circ} \mathrm{C}$, then $3 \mathrm{ml}$ of the reagent DinitroSalicylicacid(DNSA) Prepared in method Miller was added ${ }^{[14]}$.

Tubes were immersed in boiling water bath for 5 minutes to stop the reaction, and then cooled to the laboratory temperature.

The amount of glucose released was then measured using the spectrophotometer 1700 optical spectrophotometer UV $550 \mathrm{~nm}$. Standard curve of pure glucose was prepared using the following concentrations : $(0.01,0.02,0.03,0.04,0.05$ $\mathrm{mg} / \mathrm{l})$ following the same above procedure.

The efficacy of cellulase enzyme was determined by enzyme activity unit (U).

\section{Results and Discussion}

This work involves isolation and identification of the following fungi from the root of wheat (Trichoderma

\section{Volume 6 Issue 7, July 2017 www.ijsr.net}




\section{International Journal of Science and Research (IJSR) \\ ISSN (Online): 2319-7064 \\ Index Copernicus Value (2015): 78.96 | Impact Factor (2015): 6.391}

harzianum, T.viride, Alternaria alternate, Fusarium solani, Aspergillus niger, Rhizoctonia solani, T.longibrachiatum and Fusarium oxysporum) depending on the taxonomic references ${ }^{[10]}$.

The solid media method was used to determine the capacity of the studied fungi in the production of cellulase enzyme. Appearance of pale zone around the fungal colony is an evidence of the degradation of carboxymethyl cellulose (CMC-Agar) by the enzyme cellulase produced by these fungi as a result of the disintegration of cellulose into simple sugars. The susceptibility of the fungi isolates to the production of cellulase enzyme was calculated from the above relationship $^{[11]}$.

All fungi gave positive results with differed levels in their ability to produce cellulase enzyme (Table 1). T.viride produce the highest efficiency in the degradation of carboxymethyl cellulose, it was observed that the pale zone of decomposition around the fungal colony began from the second day of incubation and continued to increase in the zone diameter with the incubation period until the fifth day where it reached $(7.1) \mathrm{cm}$ in diameter.

This result indicate that T.viride have the highest potential for production of cellulase enzyme which is amounted (6.14). Other fungi showed variable ability for enzyme production as, F.solani and A.niger, which have good susceptibility to the enzyme production (4.9) and (4.7) respectively. While the fungi T.longibrachiatum, $T$. harzianum, Alt. alternate showed the following efficiency in the enzyme production $(4.4,4.3$ and 3.4$)$ respectively.

F.solani, F.oxysporum fungi showed weak production ability of the enzyme (3.3 and 3.0) respectively.

From the above results we conclude that there is a direct correlation between the pale zone diameter of the decomposition and the efficiency of fungi in the enzyme production.The fungi of high ability to produce the enzyme gave large pale zone diameter of the decomposition, except for R. solani and F. oxysporum.

The solid media method was used in the production of (alpha and beta-amylase, cellulase, bactenase, and lipase) by bacteria, mold and yeast to analyze plant residues of orange peel and pulp ${ }^{[4]}$. The results were demonstrated by Omosajola and Jilani when 61 species of fungi were isolated from root regions of a number of plants ${ }^{[8]}$.

As it was mentioned that T. reesei was one of the best fungi to produce cellulase enzyme when using solid media method [12]

Also others confirmed that the fungi Trichoderma species is one of the most productive fungal of the enzyme cellulase $^{[15]}$.

Table 1: Ability of deferent fungi to produce cellulase enzyme using solid media (CMC-Agar)

\begin{tabular}{|c|c|c|c|c|}
\hline Fungi Type & $\begin{array}{c}\text { Beginning of } \\
\text { Decomposition }\end{array}$ & $\begin{array}{c}\text { Colony zone per cm for Fungal } \\
\text { growth after five Days }\end{array}$ & $\begin{array}{c}\text { Decomposition of the Five } \\
\text { days growth per cm }\end{array}$ & $\begin{array}{c}\text { Fungal ability for } \\
\text { Enzyme production }\end{array}$ \\
\hline T.viride & the second day & 1.3 & 7.1 & 6.14 \\
\hline F.solani & the second day & 2.1 & 6.3 & 4.9 \\
\hline A.niger & the second day & 1.4 & 5.8 & 4.7 \\
\hline T. harzianum & the third day & 1.3 & 5.6 & 4.4 \\
\hline T. longibrachiatum & the third day & 1.8 & 5.5 & 4.3 \\
\hline Alt.alternata & the third day & 1.2 & 4.8 & 3.4 \\
\hline F. oxysporum & the second day & 2.1 & 2.2 & 3.3 \\
\hline R. solani & the second day & 1.7 & 2.5 & 3.0 \\
\hline
\end{tabular}

The enzymatic efficacy study of different fungal species using the mendal liquid media showed a difference in capacity in the production of cellulase enzyme (figure 2) .

T. viride gave the highest efficacy of cellulase enzyme after 7 days of the incubation, reaching to (4.39) $\mathrm{U} / \mathrm{ml}$, this indicates that $T$. viride fungus is the highest productivity of cellulase enzyme.

\section{While T.harzianum, A.niger, A.alternata,} T.lonqibrachiatnm, and F.solani fungi gave efficient capacity in the enzymatic production respectively (3.94, $3.72,3.52,3.17$ and 3.14$) \mathrm{U} / \mathrm{ml}$.

Both $F$. oxysporum and $R$. solani fungus were the lowest productive of cellulase enzyme, (2.58 and 2.04) U/ml respectively. The results obtained by the liquid medium were consistent with the results of the solid media, except for the fungal T.lonqibrachiatum which is superior of both A.niger and T. harzianum in the production of the enzyme. However the solid media results are not similar to that of the liquid media in the enzyme production ${ }^{[11]}$.
They explained these finding as species Trichoderma which give the isolate T.viride is the standard cellulase production fungi, reaching to $(4.67 \mathrm{U} / \mathrm{ml})$.

The weakness of some isolates in the production of cellulase enzyme can be explained as either the incubation period is not enough to stimulate fungi for enzyme production, or due to the differences in the ability of fungi to exploit the media of breeding, and inappropriate $\mathrm{pH}$ of the media of this fungi ${ }^{[1,5]}$. However the efficacy of the cellulase enzyme production by the fungi varies by different species ${ }^{[12]}$.

Figure 2 demonstrate the biomass of different fungi, changes in the $\mathrm{pH}$ of cultured media due to incubation of fungi and the activity of produced cellulase enzyme. The maximum biomass reached $(8.96 \mathrm{~g} / \mathrm{L})$ for T.Viride, the isolate that gave the highest efficacy of the cellulose enzyme.

The lowest biomass was reached $(4.65 \mathrm{~g} / \mathrm{L})$ for R.solani which gave less efficacy of enzyme cellulase production ${ }^{[16]}$, the maximum productivity of the biomass obtained was from T.viride $(9.24 \mathrm{~g} / \mathrm{L})$. 


\section{International Journal of Science and Research (IJSR) \\ ISSN (Online): 2319-7064 \\ Index Copernicus Value (2015): 78.96 | Impact Factor (2015): 6.391}

The final $\mathrm{pH}$ was reduced for the most fungi, initially $\mathrm{pH} 6$, except A.niger and Saccaromyces cerevisae which had a slightly higher initial $\mathrm{pH}(6.24,6.28)$ respectively. The reason for the reduction of the final $\mathrm{pH}$ is due to the addition of some organic acids in the growing media or growth of fungi and their activity in the production of cellulase enzyme. While the highest $\mathrm{pH}$ is due to hydroxyl $\left(\mathrm{OH}^{-}\right)$ release due to metabolic processes ${ }^{[15]}$.

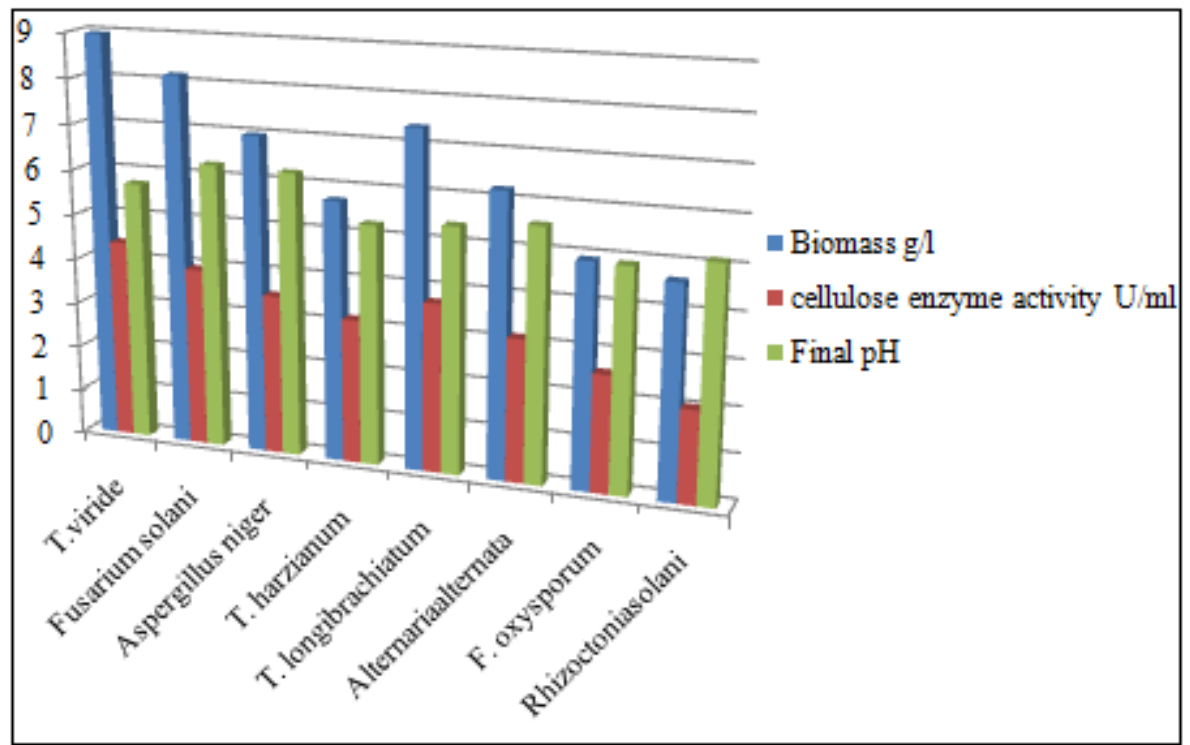

Figure 2: The ability of fungal isolates to produce cellulase enzyme using liquid Mendel media (Each value is an average of three replicates)

Figure 3 demonstrate the effects of different carbon sources on the enzyme cellulase production by T.viride after 7 days of incubation. Seven different types of sugars were used as carbon sources, added to the cultured media at a concentration of $(10 \mathrm{~g} / \mathrm{l})$ for the growth of T.viride (as one of Trichoderma which is one of the most productive fungi for the enzyme cellulase). There are clear variation in the production of cellulase enzyme according to the added carbon source to the nutrient media. The carbon source sucrose gave the highest enzyme efficacy $(3.87 \mathrm{U} / \mathrm{ml})$, followed by (CMC) which gave an enzymatic efficacy (3.28 $\mathrm{U} / \mathrm{ml})$ then the cellupiose gave $(3.01 \mathrm{U} / \mathrm{ml})$.

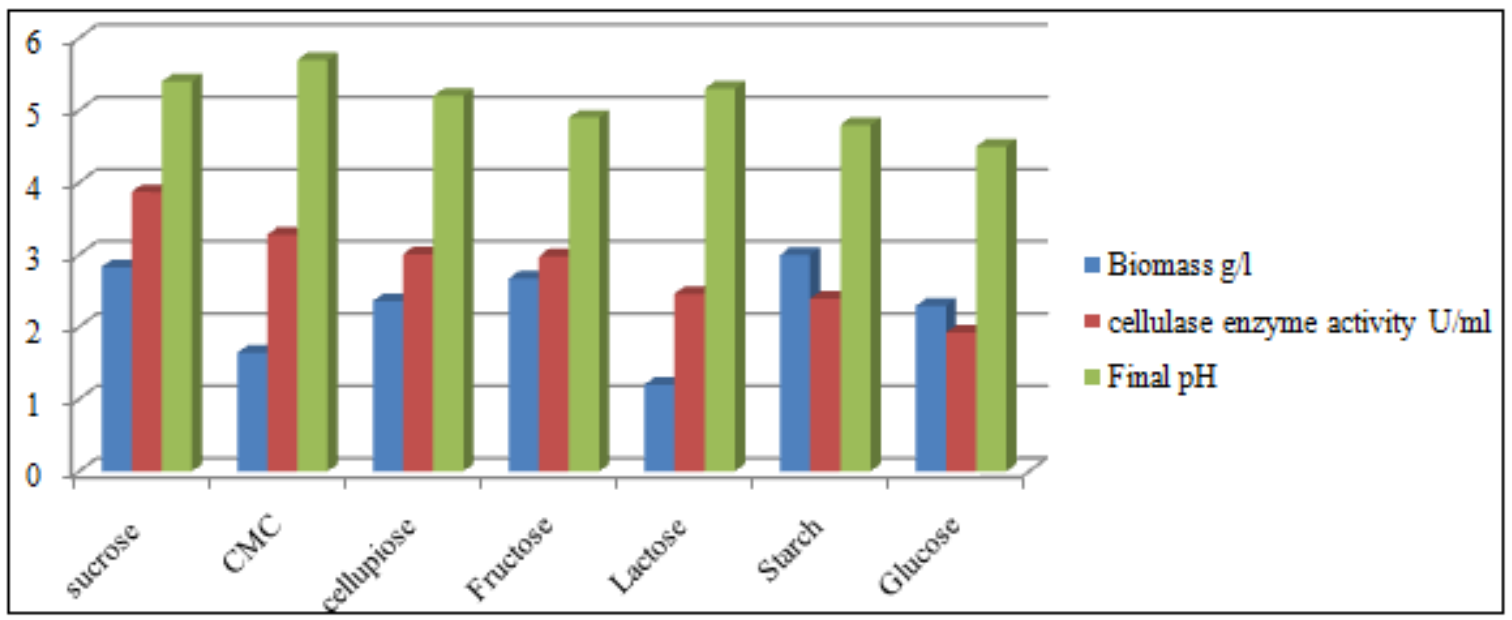

Figure 3: Effect of various carbon sources on the production of enzyme cellulase from T.viride (after 7 days of incubation)

Other carbon sources fructose, lactose, starch and glucose have less effect in the enzymatic efficiency $(2.98,2.46,2.39$, 1.92) $\mathrm{U} / \mathrm{ml}$ respectively, in the other hand sucrose have the highest enzyme beta-glucosidase production from $T$. reesei, [4,14].

Using cellupiose as a carbon sources have effective cellulose enzyme production $(2.48 \mathrm{U} / \mathrm{ml})$.
These finding are in contras of the other study using several carbon sources on the production of cellulase enzyme by fungi isolate A.niger ${ }^{[9]}$.

Carboxymethyl cellulose gave the highest efficiency for the production of cellulase enzyme.

CMC as a polysaccharides for the production of cellulase enzyme was not optimal as a carbon source for the production of the enzyme, according to the fact that the

\section{Volume 6 Issue 7, July 2017} www.ijsr.net 


\section{International Journal of Science and Research (IJSR) \\ ISSN (Online): 2319-7064 \\ Index Copernicus Value (2015): 78.96 | Impact Factor (2015): 6.391}

melting of this sugar in culture media leads to increased viscosity which is negatively affects the aeration of the culture media and thus the difficulty of exploiting the nutrient media by the fungi (figure 3 ).

Starch was the highest productivity of biomass for the carbon source $(3 \mathrm{~g} / \mathrm{l})$, followed by sucrose with a productivity $(2.83 \mathrm{~g} / \mathrm{l})$ then fructose , cellupiose, glucose, CMC $(1,64,2.29,2.36,2.67 \mathrm{~g} / 1)$ respectively. The least biomass found in lactose $(1.20 \mathrm{~g} / \mathrm{l})$. As previously mentioned, starch as a source of carbon when added to the culture media for T.viride fungi gave $(1.94 \mathrm{~g} / \mathrm{l})^{[13]}$.

\section{Conclusion}

1) There is no relationship between biomass and enzymatic effectiveness when adding different carbon sources to the culture media of the fungus T.viride.

2) The final $\mathrm{pH}$, shows a reduction reaching to 6 in all carbon sources, and this is because these sources act to stimulate the fungus for producing organic acids during metabolic processes that increase the acidity of the cultured media.

\section{References}

[1] Ang, S. K., Shaza, E. M., Adibah, Y., Suraini, A. A. and Madihah M. S (2013). Production of cellulases and xylanase by Aspergillus fumigatus SK1 using untreated oil palm trunk through solid state fermentation. Process Biochemistry 48: 1293-1302.

[2] Liu J. and Hu H. (2012). Role of cellulase binding domains in the adsorption of cellulase onto fibers and its effect on the enzymatic beating of bleached kraft pulp. Bioresources 7(1):878-892.

[3] Liang, X., Huang, Y., Hua, D., Zhang, J., Xu, H., Li, Y. and Zhang, X. (2012) .Cellulase Production by Aspergillus sp. on Rice Grass (Spartina spp.) under Solid-State Fermentation. African Journal of Microbiology Research , 6, 6785-6792.

[4] Rana S. and Kaur M.(2012). Isolation and screening of cellulase producing microorganisms from degraded wood.IJPBSF.2(1):10-15.

[5] Deswal D., Khasa Y. P. \& Kuhad R. C.(2011). Optimization of cellulase production by a brown rot fungus Fomitopsis sp. RCK2010 under solid state fermentation.Bioresour. Technol.102:6065-6072.

[6] Omojasola, P. F.; jilani, O.P. and Ibiyemi, S.A. (2008). Cellulase production by some fungi cultured on pineapple wastes. Nature and Science. 6(2). Issn: 64-78.

[7] Mandels, M. and Weber, J.(1969). The production of cellulases. Adv Chem Ser 95:391-414.

[8] Omosajola P.F,Jilani O.P. (2008). Cellulase production by Trichoderma longi,Aspergillus niger,Saccaromyces cerevisae cultured on wast materials from orange.Pak.J.Biol.Sci., 11:2382-2388.

[9] Oyeleke, S.B., Oyewole, O.A., Egwim, E.C., Dauda, B.E.N. and Ibeh, E.N. (2012). Cellulase and Pectinase Production Potentials of Aspergillus niger Isolated From Corn Cob. Bayero Journal of Pure and Applied Sciences, 5, 78-83.
[10]Ellis, M.B.(1971) Dematianceoushypomycetes. Common wealth mycological Institute. kew, surrey, England. 608 pp.

[11] Singhania R. R., Sukumaran R. K., Pillai A., Prema P, Szakacs G. \& pandey A. (2006). Solid state fermentation of lignocellulosic substrates for cellulase production by Trichoderma reesei NRRL 11460.Indian J.Biotechnol.5:332-336.

[12]Wen Z., Liao W., Chen S. (2005). Production of cellulase by Trichoderma reesei from dairy manure. Bioresour. Technol. 96: 491-499.

[13] Vinod Kumar Nathan, Mary Esther Rani,Gunaseeli Rathinasamy, Kannan Narayanan Dhiraviam and Sridhar Jayavel. (2014). Process optimization and production kinetics for cellulase production by Trichoderma Viride VKF3 SpringerPlus.3:92.

[14] Miller. G. L. 1959, Use of dinitrosalicylic and reagent for determination of reducing sugar. Analytical Chemistry.31: 426-428.

[15] Toor Y. and Ilyas U. (2014). Optimization of cellulase production by Aspergillus ornatus by the solid state fermentation of Cicer arietinum. Am. J.Res. Commun. 2(1):125 141.

[16] Pothiraj, C., Balaji, P. and Eyini, M. (2006). Enhanced Production of cellulases by Various Fungal Cultures in Solid State Fermentation of Cassava Waste.African Journal of Biotechnology, 5, 1882-1885. 